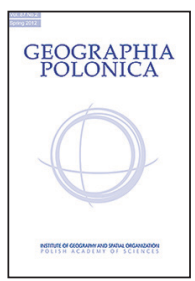

\title{
INNER DIVISIONS OF THE CZECH REPUBLIC
}

\author{
Tadeusz Siwek \\ University of Ostrava \\ Faculty of Science, Department of Human Geography and Regional Development \\ Dvoráḱkova 7, 70103 Ostrava: Czech Republic \\ e-mail address: tadeusz.siwek@osu.cz
}

\begin{abstract}
The article presents the most significant territorial divisions of the contemporary Czech Republic with respect to the Czechs' subjective perception of them, as well as in comparison with the divisions found in Poland. The author focuses on the differences in the perception of the following territorial dichotomies: the capital - the peripheries, the city and town - the village, the borderland previously inhabited by Germans (commonly referred to as the Sudetes Region and known even more widely as Sudetenland) - the interior of the state, and the perception of the cultural, historical, religious and administrative regions. All of the issues discussed are documented by statistical data and the author's own research, as well as observations made by the author who has lived in the country since his birth.
\end{abstract}

\section{Key words}

territorial division • perception • mental maps $\cdot$ cultural regions $\cdot$ administrative regions $\cdot$ Czech Republic

\section{Introduction}

In most countries with an area larger than, for instance, that of Luxembourg, one can notice more or less distinct internal divisions, the hierarchy and complexity of which are usually proportional to the area of the said country. Poland's southern neighbour - the Czech Republic - is a medium-sized European country and a small country in a global context. In a more general approach, necessary in the case of large-scale studies, the country is usually perceived as a relatively homogenous geographical region. Yet, at a closer look, its internal divisions emerge; there may be so many of them that it is difficult to choose the most important ones, which determine the Czech regional structure. Some of them are more visible than others, some of them are similar to divisions in other countries, but there are also specifically Czech divisions. One may attempt to analyse certain aspects of the internal variety, as geographers from Olomouc have done (Halás \& Klapka 2010), but it is difficult to choose a method, which allows one to determine the most significant regional divisions of the country.

The best method for the evaluation of the significance of a particular division seems to be perception.
Due to this, mental maps are developed in the human brain, on the basis of which the image of the surrounding world is formed (Gould \& White 1974). This image is individual, but when we analyse the frequency of its occurrence in society, we can obtain knowledge concerning the most frequent mental maps, i.e. a kind of a collective mental map of a phenomenon being analysed. Hence, the article presents the geographical divisions of the Czech territory selected on the basis of their parallel perception by Czechs and Poles as observed in everyday life. The divisions presented in the article and perceived as significant for the Czechs may also be interesting for Polish geographers because of the more or less visible differences in comparison with relevant regional structures in Poland. The perception of regional divisions has also a practical dimension, such as for instance the perception of the regions by potential foreign investors (Spilková 2007). The article presents the division of the country into the capital and the peripheries, the urbanised area of the Czech cities and the Czech village, the historically determined differences between the old Germanised borderland (the so-called Sudetenland) and the interior of the country, and the division into cultural, historical, religious and administrative regions. The above-mentioned elements 
of regional variability are documented by statistical data, the author's own research, as well as observations made by the author, an inhabitant of the country, over many years.

\section{The division: the capital - the peripheries}

The first visible internal division in the Czech Republic is - just like in most other countries - the disproportion between the capital and the remaining parts of the country. Prague is one of the disproportionately large capitals in Europe in comparison with the remaining part of the country, just like Vienna or Budapest, which is the consequence of the fact that in the past it used to be the capital of a larger country than nowadays. On 31 December 2009 the population of Prague was 1,249,000 inhabitants (Čsú 2010a), which was 11.9\% of the population of the entire country. In comparison with Warsaw, its position is more unequivocal, not only because of the fact that the population of Warsaw is only $4.5 \%$ of the population of entire Poland. There are cities in Poland (such as Kraków or Gniezno), which used to be capitals in the past, as well as cities, which are only a little smaller than Warsaw. In the Czech Republic, Prague has a dominant position not only with respect to the population, but also in the economic and cultural sense. It is on the top level of the comprehensively understood Czech settlement hierarchy (Hampl et al. 1978, 1987). The capital city's position is perceived differently by the Czechs. A positive perception of the capital occurs above all among its inhabitants and among people living outside Prague who want to identify themselves with the country or the nation. These people underline the indisputable role of Prague in Czech culture and the economy. This is confirmed by statistical data. For instance, the average remuneration in 2007 was 25,914 Czech crowns in Prague, while the national average was 18,976 Czech crowns, and remuneration was the lowest in the Karlovy Vary Region: 16,367 Czech crowns (ČSÚ 2008). The unemployment index in Prague has remained the lowest in the country for the last 20 years. In the first quarter of 2010, despite the economic crisis, it was only $3.7 \%$, while the national average was $7.2 \%$ and the maximum indices in the peripheries were as follows: Uničov 21.2\%, Varnsdorf 17.9\%, Bruntál 17.8\%, Frýdlant $17.7 \%$.

A negative perception of Prague occurs most frequently among people living outside the capital, and it is usually subjective. The image of the capital as a city living off the remaining part of the country is not surprising as it occurs also in other countries. It is enough to consider the typical image of Warsaw as perceived by an average Pole. The subjectively negative attitude of the people towards the capital is confirmed by research. I would like to quote here an unpublished fragment of research on the perception of space in Czechoslovakia carried out in 1984 among 100 geography students at the Charles University in Prague (Siwek 1988). Although this research was carried out a long time ago, it is quite improbable that the re- sults would be different today. Of all the respondents, 35 people were from Prague and 65 from outside the capital. On a scale defining the attitude to a particular region from 0 (maximum antipathy) to 10 (maximum sympathy), they placed their own place of residence at a level of 7.65; the inhabitants of Prague - a little lower (7.46), while students from outside Prague - higher (7.75), but the difference is within the limits of a statistical significance. The evaluation of Prague by students from other cities was considerably lower: 5.45. The difference is clear, and those people doing the evaluating were students of a Prague university who knew the city very well.

The most extreme opposition to Prague is the Czech peripheries. This subject has been very popular among Czech geographers (Havlíček \& Chromý 2001; Novotná 2005, Jeřábek et al. 2004). One of the basic indices of peripherality in a macro-regional scale is a considerable distance from the capital and a small distance from the border. Since Prague is situated in the western part of the country, the eastern regions of the Czech Republic are automatically peripheries in the macro-regional scale (Blažek \& Csank 2007). To some extent, even Moravia is peripheral, but the most peripheral part is the Czech part of Silesia (Siwek 2006). On the macro-regional scale, accessibility should also be taken into consideration in addition to distance. Because of the irregularity of the Czech borders which were drawn up in the early Middle Ages, in many places Czech territory runs into the area of the neighbouring countries forming so-called "lobes" or "headlands". Poland has only a few such areas, the best known of which is Turoszów Lobe (Worek Turoszowski). In the Czech Republic the territorial "headlands" are discussed during geography classes. Their names derive from the names of towns located within them: Aš, Šluknov, Frýdlant, Broumov, Javorník, Osoblaha and Lanžhot. These are the real Czech peripheries, poorly populated, inaccessible from the interior and underinvested. In the pre-war period they were inhabited almost entirely by Germans. It is not surprising that during World War II, in 1942, the Czech President-in-exile, Edvard Beneš, was considering the alternative of a voluntary renouncement of six territorial "headlands" in return for the displacement of Germans from the remaining territories (Dami 1976). This never happened but the very fact of taking such a possibility into consideration proves that the above mentioned peripheries were actually treated as unnecessary areas.

The remaining borderland areas, although certainly not all of them, can also be included in the peripheries. The borderland areas located on communication routes or near well-developed areas across the border will prosper. As the borders disappear, they have assets which areas located in the interior do not have (Jeřábek et al. 2004).

Apart from this, there are also so-called internal peripheries in the Czech Republic - just like in other countries. They are frequently located very close to large cities but they have no proper connection with the main routes, no proper infrastructure and show no signs of dynamic economic activity (Musil \& Müller 2008). 
A map published by Musil and Müller indicates that they are exclusively rural areas. There are quite a number of them, although they are not large and they do not constitute a widespread compact area. This results from the configuration of the Czech Republic, a dense road and railway network and a relatively large number of small towns. Thus, spatial marginalization refers only to a small area of the Czech Republic.

\section{The division: city and village}

Another important Czech spatial division is the division into cities/ towns and villages. Such a division also occurs in all the countries of the world, and the size of the urban population is one of the indices of the progress of civilisation. The Czech Republic is one of the most urbanised countries in the world, even though in the European context it is nothing extraordinary (Horská et al. 2002). This division of the Czech Republic is presented as a topic of cultural geography by Heřmanová et al. (2009).

According to data presented in the latest Statistical Lexicon of Communes, there were 527 cities/towns in the Czech Republic (ČSÚ 2005). According to data provided by the Czech Statistical Office, as at 1 January 2010, the number of cities/towns had risen to 594, because several dozen historical towns had regained their status lost at some point.. At the beginning of 2010, the only city with a population of more than 1 million was Prague (1,249,000); Brno, Ostrava, Plzen, Liberec and Olomouc had a population of more than 100,000. In total, 132 Czech towns had a population of more than 10,000, 139 had a population of 5,000 to 10,000, and 217 - just 2,000 to 5,000. In addition, 106 of the smallest towns had a population of fewer than 2,000 and in the two smallest towns there lived fewer than 100 inhabitants: Přebuz in the Karlovy Vary Region (74 inhabitants) and Loučná pod Klínovcem in the Usti nad Labem Region (90 inhabitants). There are no such towns in Poland.

Some of the Czech rural communes have more inhabitants than the above mentioned towns. Three of the Czech communes which do not have the status of a town have a population of more than 5,000 (the largest one of these, Jesenice near Prague, has a population of 6,500 ), and 11 other communes have a population of more than 4,000 (Čsú 2010b). These are usually communes in the conurbations of large cities (e.g. Prague, Ostrava).

The Czech statistics do not, however, include these micro-towns in all their reviews. Most frequently they use a quantity criterion according to which, towns are communes with a population exceeding 2,000 inhabitants. In 2010 they were inhabited by $73.7 \%$ of the population of the Czech Republic. At such a low threshold, the level of urbanisation seems relatively high - for instance, higher than in Poland, where the population of cities is $62 \%$ of the entire population of the country, but it follows from the above, that the majority of Czech towns are small towns. The typical Czech town is inhabited by 15-50 thousand people (there are 67 such towns).
In the last 10-20 years, there has been some stagnation, and even decline in the number of inhabitants of Czech towns (Andrle 2001). Because there has been a natural population decline in the country since 1994, and the increase in population is due almost entirely to migration alone (Burcin et al. 2008), the growth of Czech towns has also stopped. The birth-rate is low or non-existent, and suburbanisation means that people move from cities to the surrounding suburbs.

The post-communist industrial towns also show a decline in population as employment opportunities have diminished there (Ostrava, Ústí nad Labem, Kladno) after the transformation. The situation is similar in other European countries, in particular in Central and Eastern Europe.

Despite the stagnation in the population growth, most Czechs perceive towns/cities as more attractive places in which to live than a village. They are the major areas of regional development (Blažek \& Uhlir 2002). Young people leave the villages in large numbers, especially in the peripheries. This occurs in many European countries and in the world as well, but in the Czech Republic it is more extreme. Young people's migration from villages to towns/cities is neither curbed by a strong attachment to tradition and homeland nor by a necessity to run the family farms, as it is in other countries. After the communist period (after reprivatisation), there are not many farms left in the Czech Republic which can boast a tradition of many generations. The former cooperatives (Jednotná zemědělská družstva) and state-owned farms (Státní statky), which did not collapse, were transformed into companies and new types of cooperatives. Some descendants of the former owners did come back to the villages, but there were many more people for whom agricultural work was not a return to tradition but the beginning of modern and effective farming in the West European style (Perlín \& Šimíčková 2008). The Czech village is attractive for such entrepreneurs but their modern farms do not require much labour. Modern farms sometimes actually only employ a few people and this is why Czech villages are still becoming depopulated. The only exception is found in the rural areas near to large cities, where there are more and more people who want to combine the pleasures of living in a village with a small distance to the city/town. Thus, satellite communities for the rich grow there. Suburbanisation, which causes cities to sprawl, as the urban tissue "pours" outside, is especially advanced in Prague (Ouředníček 2003), but also occurs in medium-sized Czech cities. The population growth in rural communes near large cities is the factor producing the slight population growth in rural areas as a whole (Andrle 2001).

\section{The division: borderland and interior}

The Czech borderland is not only a geographical but also a historical and political concept, perceived as a problem both by politicians and by society. Until 1945, more than 3 million Germans lived in a zone reaching 10 to $100 \mathrm{~km}$ deep from the entire German and Austrian border and from nearly the entire 
Polish border. This area is commonly referred to as the Sudetenland, even though geographically this name is misleading (Chromý 2000). The pejorative colloquialism "Sudet'ák" is well known to almost all Czechs, and it means to them a German from the former Czechoslovakia. The problem occurring in this area is to some extent equivalent to that occurring in the Polish "recovered territories", with the difference that the Czech borderland never belonged to Germany and formed a whole with the remaining historical Czech lands, both during the time of the independent Czech state and during the time when the land belonged to Austria.

The territory constitutes one third of the country. The area given to Germany in 1938 as a result of the Munich Pact was 28,870 $\mathrm{km}^{2}$ (36.6\% of the present territory of the Czech Republic). Because of its location near the border, it largely coincides with the Czech peripheries. After World War II the area was returned to Czechoslovakia and almost the entire German population was relocated to Germany as a result of the Potsdam Agreement of 1945 (Staněk 1991). People from the interior as well as from Slovakia replaced them. In some of the German borderland areas the population never reached the numbers of pre-war times, and the land use there was radically changed (Bičík \& Štěpánek 1994). The number of people who were born in these regions is still lower than in the Czech interior (Heřmanová et al. 2009). In many cases these lands are nowadays simply used for recreation (Fialová 2001).

Although the common perception of the Sudetenland functions in the Czechs' collective consciousness, many of them have a problem with the spatial visualisation of its range. Many Czechs have no idea that it used to be one third of the territory of the present Czech Republic and that the population was one third of the pre-war population of the country. Ignorance in this respect is typical especially for adolescents.

Many Czechs are subconsciously afraid that the descendants of the relocated Germans may demand the return of their property left behind there, and they are aware of the fact that this would constitute a threat to the Czech Republic, even when they are not able to specify the extent of this threat. This is the reason for the continuous use of the Sudetenland as the post-German borderland in the battles in the internal political stage. In 2009 the Czech President, Václav Klaus, made use of it when making the signing of the Lisbon Treaty conditional on the acquisition by the Czech Republic of an exception in EU law, regarding the possibility of the application of European law to the recovery of property by the descendants of Czech Germans. This argument was not directed against the quite improbable claims of the Sudeten Germans, but was meant to strengthen the position of the Czech President, and he did indeed succeed in this. The majority of Czech politicians agreed with him, from the right to the left side of the political stage. This shows that the problem of the Sudetenland is not really just a historical problem for Czechs.

\section{Divisions into historical and cultural regions}

The Czech state consists of three historical parts, and these parts comprise some cultural and historical regions of lower rank. The historical parts: Bohemia, Moravia and Silesia are at the top of the hierarchy of Czech regions. This can be proved, for instance, by the fact that the Czech state coat of arms is a combination of the coats of arms of these historical parts. Presenting the Czech parts to Polish readers one should pay attention to a certain inconsistency in the names, which may be a source of error. The name "Czech state" is used in the Polish language to refer to the entire state, whereas for the Czechs it is just one part of the state. It is actually the largest, most populated part in which the capital city is located, but it reaches only as far as the Bohemian-Moravian Plateau. That is why in this article, in order to distinguish the Czech state from just one of its parts, the term "Bohemia" will be used. Bohemia $\left(52,000 \mathrm{~km}^{2}, 2 / 3\right.$ of the territory of the Czech Republic and 5.5 million inhabitants, i.e. $55 \%$ of the entire population of the country) and Moravia $\left(22,000 \mathrm{~km}^{2}\right.$, i.e. $28 \%$ of the territory of the Czech Republic and more than 3.1 million inhabitants (30.2\% of the entire population of the country) are both entirely within the territory of the Czech Republic and make up 93\% of the area of the Czech Republic. Only a small area of the last part - Silesia - is within the Czech state; it is $7 \%$ of the area of the country.

The position of the three historical lands - more or less corresponding to the Polish lands: for example Greater Poland, Lesser Poland and Mazovia - is not identical in the awareness of Czechs. According to research carried out in 2003, Bohemia and Moravia are very clearly rooted in the Czechs' awareness, but Czech Silesia occupies a much worse position (Siwek \& Bogdová 2007, 2008). It is perceived rather as a cultural region of lower rank, like Hana, the Valassky Region, the Moravian-Slovakian Region and the Chodsko Region. This is related to its separate history, smaller area and smaller population in comparison with the two major parts of the Czech realm.

The level of perception of the Czech regions was examined in 2003 using a sample of 1,203 respondents from the entire territory of the Czech Republic. The result of the study is a mental map of the historical and cultural regions of the Czech Republic (Siwek \& Bogdová 2007, 2008). The position of Czech Silesia in the Czechs' awareness reaches approximately three quarters of the level of Bohemia and Moravia. This level of territorial identity is still higher than the level of cultural identity in those cultural regions of a lower rank most rooted in the Czechs' awareness (Siwek 2007).

The majority of the inhabitants of Moravia have their own territorial identity and a general sense of identity (Daněk 1993; Siwek 2002a). Moravia has never attempted to separate from the remaining part of the country but from time to time there are certain tendencies to weaken its dependence on Prague (Žáček 1995). Also other citizens in the country perceive it as a separate region (Siwek \& Bogdová 2007). 
As opposed to the culturally and linguistically homogenous Bohemia, more dialects and other elements of a specific folk culture have survived in particular regions in Moravia. These regions were also more frequently indicated by respondents during the study of territorial identity in 2003 as their most important places of identity reference.

Some Moravian people are convinced that Moravia has an unequal position compared to Prague and Bohemia, a belief that was made use of after the fall of the communist system in 1989. Movements in favour of the acceptance of a separate Moravian nationality and greater empowerment in managing their affairs, and - following on from this - a tendency to reinstate the former administrative identity of Moravia, never encountered before, now came to the fore (Mareš 2003). In the 1991 census, Moravian political groups forced through the acceptance of the Moravian and Silesian regional identity as separate nationalities. As many as $1,363,300$ inhabitants of Moravia then declared Moravian nationality, i.e. $1 / 3$ of the province's population and $13.2 \%$ of the population of the entire country. In another census in 2001 the number of supporters of a separate Moravian nationality declined, however, to 373,300 , i.e. $12 \%$ of the population of Moravia and $3.6 \%$ of the population of the entire country. Such a significant decline in willingness to declare a regional identity as nationality was undoubtedly caused by associations with the division of Czechoslovakia in 1993 and the growth of Czech society's fears of accentuating other divisions (Siwek 2002a).

The area of Silesia within the Czech state's borders is 5.5 thousand $\mathrm{km}^{2}$, i.e. $7 \%$ of the country's area; its population is 0.7 million inhabitants, i.e. $7 \%$ of the Czech population. The borders of Czech Silesia can be reconstructed on the basis of the Austrian administrative borders, but they are less unequivocal than the Czech - Moravian border. The Moravian - Silesian border is a complicated one, with many Moravian enclaves in Silesia. In the distant past, Czech Silesia had already twice been administratively joined to Moravia (1783-1849 and 1927-1948), and in the communist period, from 1949 until the establishment of the present administrative division in 1998, it disappeared from administrative maps (Siwek 2007). Ostrava (only a part of the city) is the largest city of Czech Silesia. The historical capital of Austrian Silesia - Opava - is nowadays a relatively small town, and Český Těšín, the western part of the former capital of Cieszyn Silesia, is even smaller. Only a small part of the local Czech population in Opavian Silesia have Silesian identity. The immigrant population which has dominated in Czech Silesia since the mid-20th century (in Opavian Silesia, as a result of the relocation of the Germans, and in Cieszyn Silesia, as a result of migration related to industrialisation), does not have any such identity, and the indigenous Polish population in Cieszyn Silesia most frequently declares Polish nationality. In 1991 only 44,000 inhabitants declared Silesian nationality, i.e. 5-6\% of the popu- lation of Czech Silesia (Siwek 1995). In the census of 2001 less than 11,000 people declared Silesian nationality, i.e. $24.5 \%$ of the number in 1991 . This does not mean that the Moravian and Silesian identity is disappearing. Research proves that it does exist, although most of the people who proclaim it do not have a need to politically declare their regional identity as their nationality.

The lower levels of the regional hierarchy on the mental map of an average Czech are occupied by the cultural and historical regions with ethnographic specificity (Heřmanová et al. 2009). They correspond to the Polish Kashubia (Kaszuby), Kurpie and Podhale regions. Regions of this type occur more frequently in Moravia than Bohemia, where the only more distinct ethnographic region is the Chodsko Region in the western borderland of the Czech Republic (Domažlice). In Moravia, there are several such regions: Haná near Olomouc, the Moravian-Slovakian Region on the border with Slovakia, the Valašský Region in the Beskidy Mountains to the south of Silesia, and a little less distinct, the Horácký Region near Jihlava and the Laski Region, adjoining Silesia between Ostrava and Nový Jičín.

Among the more frequently mentioned regions in the 2003 study there was also the industrial region of Ostrava, and less distinct regions were also mentioned sporadically, such as the Sudetes, Cieszyn Silesia, the fragmentary Moravian-Slovakian region, Horňácko, etc. Sometimes respondents created their own names for regions, deriving them from the names of mountains: the Giant Mountains (Krkonoše), the Ore Mountains (Krušné horsko) or the Bohemian Forest (Šumava). They usually function in Czechs' awareness as regions of recreation and tourism. Recently, new regions have been created in the Czech Republic, which invoke old history (the Prajzsky Region, i.e. the Prussian region near Hlučín) or fairy tales and mythology for the purpose of promoting tourism (Rumpel \& Siwek 2006).

\section{Religious divisions}

From the second half of the 20th century onwards the Czech Republic has been known as one of the least religious countries in the world. This is the consequence of an exceptional series of events in Czech history, including (the Hussites, followed by Protestantism, obligatory recatholicisation during the reign of the Habsburgs, and during the communist period, almost complete removal of the church from social life), as well as the Czech national character which has been described in many varied publications (Daněk \& Štěpánek 1992; Srb 1997; Havlíček 2006; Siwek 2005, 2006; Heřmanová et al. 2009).

In the last census only $32 \%$ of Czechs declared membership of any church, and just one quarter of this number, i.e. approximately $7 \%$ of all inhabitants of the Czech state, participate in mass at least once a week (Spousta 1999). Despite historical perturbations, the 
most popular church in the Czech Republic is the Catholic Church and $80 \%$ of Czechs who believe in God are members of this church. Despite traditions, only a few percent of the population belong to the other remaining churches, i.e. the Protestant churches, including the Unity of the Brethren and the national Hussite Church (Čsú 2004a).

This article is too short to present a comprehensive analysis of the Czechs' religiosity, but it is worth considering the spatial distribution of people declaring their membership of a church in the censuses of 1991 and 2001, in which for the first time after the fall of the communist system, membership of a church was once again recorded (Daněk \& Štěpánek 1992). As is apparent from the census, Czech religiosity changes quite regularly from the north-west to the south-east of the country. The results of the 1991 and 2001 censuses do not differ very much in this respect (Havlíček \& Hupková 2008). Bohemia is more atheist, while Moravia - more religious. Most of the people who do not declare membership of any church live in the northwestern part of the country - in the regions bordering Saxony, i.e. the former East Germany. These are the following districts: Most (79.9\% atheist), Děčín (78.9\%), Chomutov (77.9\%) and Teplice (77.9\%); (Čsú 2004a). They form the smallest proportion of the population in Moravia and in Czech Silesia, i.e. in areas bordering on Slovakia. In the 2001 census the smallest number of atheists was recorded in the following districts: Uherské Hradiště (27.6\%) and Žd'ár nad Sázavou (32.0\%).

The reasons for such a spatial distribution can be found in pre-war Czechoslovakia, or even earlier (Daněk \& Stěpánek 1992). A larger number of convinced atheists was already recorded in Bohemia than in Moravia in the Czechoslovakian censuses of 1921 and 1930 - this is long before the takeover of power by the Czech communists. In Bohemia as many as $10.2 \%$ of the inhabitants declared in 1930 that they did not belong to any church, while in Moravia and in the Czech part of Silesia it was only $2.9 \%$ of the population (ČSÚ 1935).

In most European states, more people who believe in God live in villages, while more atheists - in cities. Such a correlation also occurs in the Czech Republic (Siwek 2006), but the decline in the number of people believing in God along the axis: north-west - south-east is so significant that for instance the number of people believing in God living in villages located near the border with Saxony is three times smaller than the number of people believing in God living in the towns of southern Moravia.

In social awareness, there exists a stereotypic division into the atheist Bohemia and Catholic Moravia. This can be proved for instance by commentaries and electoral analyses concerning the Czech Christian democrats, i.e. the People's Party. Indeed, virtually all analysts mentioned that the southern and eastern Moravia was the support base of this party. The majority of the country's population is also aware of the fact that in this part of the Czech state there are more churches, which are full of people and more conspicuous religious holidays. The religious division along the east-west axis is more frequently perceived as yet another difference between the two largest historical regions: Bohemia and Moravia than a division of Czech society with respect to religion.

\section{Administrative divisions}

In everyday life the Czechs, just as of many other nations, is mostly affected by the country's internal administrative division. Where one can deal with everyday affairs, to which court district or police precinct one has to report, if necessary, in which voting district one can vote, etc. depend on these divisions. The regional identity studies of 2003 confirmed that certain administrative units occupy a better position in the Czechs' awareness than some of the lesser-known cultural regions without any clearly defined borders and structures.

The administrative division of the Czech Republic has three levels: the commune (obec) - the district (okres) - the region (kraj). Local government, however, has only two levels: the commune and the region, i.e. the equivalents of the Polish commune (gmina) and voivodship (województwo). Districts do not have local governments; they are statistical and organisational units for courts of law, the police and the health service.

The basic characteristics of the present administrative structure have been inherited from the communist period. In all 77 of the Czech districts occupy almost identical territory to those existing in the years 1961-1989. There are more communes: there were 4,100 communes in 1989, whereas now there are 6,250 communes, because after the fall of the communist system the Czech authorities agreed to separate communes which had been merged against the will of the inhabitants. This number is closer to the number of 9,000 Czech villages, which originally existed in the country before the administrative integration processes. It is already known today that, too many very small communes were established then due to grass-roots initiatives. The smallest of them - Vlkov in the district of České Budějovice - has a population of only 21 people (Čsú 2005). There are no such small communes in Poland. Czech law nowadays is no longer favourable to the establishment of such microscopic communes. The minimum number of inhabitants of a commune, which wants to become independent is 1,000. Czech law does not negate, however, the existence of small communes established in the past.

The equivalents of the Polish provinces in Czech terminology are the 14 'regions' (Fig. 1): the capital city Prague, the Central Bohemian Region (the capital: Prague), the South Bohemian Region (České Budějovice), Plzeň Region (Plzen), Karlovy Vary Region (Karlovy Vary), Ústí nad Labem Region (Ústí nad Labem), Liberec Region (Liberec), Hradec Králové Region (Hradec Králové), Pardubice Region (Pardubice), Vysočina Region (Jihlava), the South Moravian Region (Brno), Olomouc Region (Olomouc), Moravian-Silesian Region (Ostrava) and Zlín Region (Zlín). Four regions have names deriving from the names of the historical parts of the country. These regional units were introduced into the Czech administrative system in 1949, which was similar to the present system. In 1961 the number of Czech regions was decreased to 8 , and in 1990 they were completely dissolved. In 1999 they were re-established following the passing of a new act 


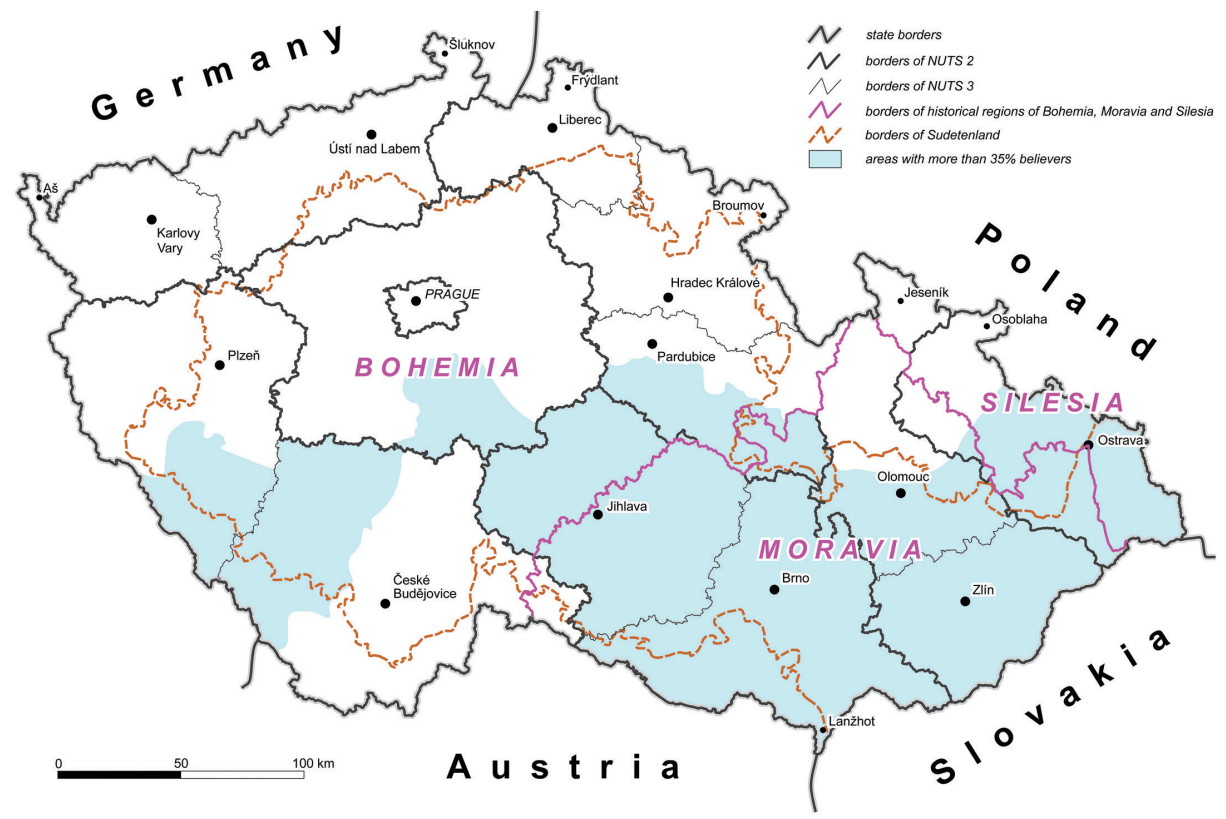

Figure 1. Czech regions. Coloured areas are those in which a share of the population above average for the country as a whole declares allegiance to one or other of the 31 churches recognised officially by the Czech authorities.

of parliament, but their local governments were only elected for the first time at the end of 2,000.

In the regional identity studies of 2003 some Czech regions associated with recreational areas were ranked relatively high. The most frequently mentioned regions were the South Bohemian Region, the Vysocina Region, the South Moravian Region, Prague and the Plzeň Region. Administrative units whose names have a geographical or historical character (such as the South Moravian Region, the Vysočina Region - The Highlands Region) occupy a higher place in inhabitants' awareness than those whose names derive from the names of the capital cities.

The Czech regions are so small, however, that in Europe they can only be considered as the level NUTS3. Because the level NUTS2 is necessary for statistical purposes, the Czechs have combined 2 or 3 smaller regions in so-called cohesion regions. There are 8 of these, the same number as the number of regions that existed in the years 1961-1990, but their borders are slightly different (Fig. 1). This proves, however, that there is an objective hierarchy of regions, which has to be taken into consideration during the introduction of reforms of administrative structures.

\section{Conclusions}

The aspects of the regional division of Czech Republic that are presented here only include those that are naturally selected. We can find many others. Heřmanová et al. (2009) describe for example the differentiation of Czech territory according to education, kind of village architecture, location of second homes etc. These examples do not create compact areas. Also other differ- ences such as differences between the more industrial northern part of the country and the southern regions of Czech Republic with predominantly agricultural areas or the difference between the lowlands along the Czech rivers and the Czech mountains and highlands situated mostly in the border areas and between Bohemia and Moravia etc. are not so clear in geographical space. These differences are less evident to ordinary people.

The divisions described in this article, more visible as they are to ordinary Czechs, are proof that regional differences in the Czech Republic are not external ones. The majority of Czechs perceive the differences between the capital, the remaining parts of the country and the peripheries, between the Czech cities and towns and rural areas, but these divisions do not lead to social tensions or disproportionate economic differences.

The awareness of the greater variety of the former German-speaking borderland in comparison to the ethnically Czech areas of the country is disappearing gradually and remains only a relict element of a political game. Almost all Czechs are aware of the division of the country into two historical parts: Bohemia and Moravia, while Czech Silesia does not function so well in their awareness. The cultural and historical division into Bohemia and Moravia coincides to some extent with other divisions, and hence, we have the central, more urbanised, culturally homogenous Bohemia and the more peripheral, rather rural and more culturally diverse Moravia. Then there is the simplified division into the more atheist Bohemia and the more traditional and religious Moravia. This is how it functions in people's awareness. The present administrative division shows a practical aspect of the internal divisions. 
In many cases, for the average Czech, this division is more important than the cultural regions moulded by history and without clearly defined borders. By preferring administrative structures, Czechs prove that one can identify with a particular administrative structure and adjust to it, even if it is not optimal.

In general, none of the above mentioned divisions creates serious problems in the everyday functioning of the state and society, neither is it any threat to

\section{References}

ANDRLE A., 2001. Demografická stagnace našich největšich měst. Urbanismus a územní rozvoj, vol. 6, no. 6, pp. 19-22.

BiČíK I., ŠTĚPÁNEK V., 1994. Post war changes of the land use structure in Bohemia and Moravia: case study Sudetenland. GeoJournal, vol. 32, no. 3, pp. 253-259.

BlaŽEK J., CSANK P., 2007. The West-East gradient and regional development: the case of the Czech Republic. Acta Universitatis Carolinae Geographica, vol. 40, no. 1-2, pp. 89-108.

BLAŽEK J., UHLíř D., 2002. Teorie regionálního rozvoje: nástin, kritika, klasifikace. Praha: Karolinum, 211 pp.

Burcin B., DrbohlaV D., KuČERA T., 2008. Možnosti migračního řešení perspektivního úbytku a demografického stárnutí obyvatelstva České republiky. Sociologický časopis, vol. 44, no. 4, pp. 653-682.

Chromý P., 2000. Historickogeografické aspekty vymezování pohraniči jako součást geografické analýzy. Geografie. Sborník České geografické společnosti, vol. 105, no. 1, pp. 63-76.

ČSÚ, 1935. Statistický lexikon obcí Republiky československé 1935. Praha: Český Statistický Úřad.

ČSÚ, 2004a. Náboženské vyznání obyvatelstva. Praha: Český Statistický Úřad.

ČSÚ, 2004b. Rozmístění a koncentrace obyvatelstva ČR: časová rada 1961-2001. Praha: Český Statistický Úřad.

ČSÚ, 2005. Statistický lexikon obcí České republiky 2005. Praha: Český Statistický Úřad.

ČSÚ, 2008. Okresy České republiky v roce 2008. Tab. 3.8. Zaměstnanci a jejich prüměrné hrubé měsični mzdy podle krajů a mista pracoviště za rok 2007. Praha: Český Statistický Úřad.

ČSÚ, 2010a. Městská a obecní statistika. Praha: Český Statistický Úřad.

ČSÚ, 2010b. Počet obyvatel v obcích k 1.1.2010. Praha: Český Statistický Úřad.

ČSÚ, 2010c. Nezaměstnanost $v$ České republice ke dni 31.12.200. Praha: Český Statistický Úrad.

DAMI A., 1976. Les frontières Européennes de 1900 à 1975: histoire territoriale de l'Europe. Genève: Médecine et hygiène, $370 \mathrm{pp}$. society. Summing up, one might state that the divisions presented may be interesting for analysts of spatial structure - including social geographers - because of their influence on the spatial processes occurring in the Czech Republic.

Editors' note:

unless otherwise stated, the sources of tables and figures are the author(s), on the basis of their own research
DANĚK P., 1993. Moravian and Silesian nationalities: a new phenomenon in the ethnic map of the Czech lands? GeoJournal, vol. 30, no. 3, pp. 249-254.

DANĚK P., ŠTĚPÁNEK V., 1992. Územní diferenciace náboženského vyznání obyvatel českých zemí 1930-1991. Geografie. Sborník České geografické společnosti, vol. 97, no. 3, pp. 129-145.

FIALOVÁ D., 2001. Druhé bydlenía jeho vztah k periferním oblastem. Geografie. Sborník České geografické společnosti, vol. 106, no. 1, pp. 36-47

Gould P., White R., 1974. Mental Maps. Pelican geography and environmental studies, New York-Baltimore: Penguin, 204 pp.

GUS, 2010. Ludność. Stan i struktura w przekroju terytorialnym. Stan w dniu 30 VI 2010r. Warszawa: Główny Urzad Statystyczny. Departament Badań Geograficznych, 121 pp.

Halás M., KlapkA P., 2010. Regionalizace Česka z hlediska modelování prostorových interakcí. Geografie, vol. 115, no. 2, pp. 144-160.

Hampl M., Gardavský V., KühnL K., 1987. Regionální struktura a vývoj systému osídlení ČSR. Praha: Univerzita Karlova, 255 pp.

HAMPL M., JeŽEK J., KüHNL K., 1978. Sociálněgeografická regionalizace ČSR. Acta demographica, no. 2, Praha: Česká demografická společnost při ČSAV, 301 pp.

HAVlíčEK T., 2006. Church-state relations in Czechia. Geo-Journal, vol. 67, no. 4, pp. 331-340.

Havlíček T., Chromý P., 2001. Př́spěvek k teorii polarizovaného vývoje území se zaměrením na periférní oblasti. Geografie, vol. 106, no. 1, pp. 1-11.

HAVlíČEK T., HuPKOVÁ M., 2008. Religious landscape in Czechia: New structures and trends. Geografie. Sborník České geografické společnosti, vol. 113, no. 3, pp. 302-319.

Heřmanová E., Chromý P. Marada M., KuČerová S., KUČERA Z., 2009. Kulturní regiony a geografie kultury: Kulturní reálie a kultura $v$ regionech Česka. Praha: ASPI Wolters Kluwer, 348 pp.

Horská P., Maur E., Musil J., 2002. Zrod velkoměsta. Urbanizace českých zemí a Evropa. Praha: Paseka, 352 pp.

JeŘÁBEK M., DOKOUPIL J., HAVLíČEK T., 2004. České pohraniči: bariéra nebo prostor zprostředkování? Praha: Academia, $296 \mathrm{pp}$ 
MAREŠ M., 2003. Etnické a regionální strany v ČR po roce 1989. Brno: Centrum pro studium demokracie a kultury, $239 \mathrm{pp}$.

MusIL J., MülLeR J., 2008. Vnitřní periferie v České republice jako mechanismus sociální exkluze. Sociologický časopis, vol. 44, no. 2, pp. 321-348.

Novotná M. (ed.), 2005. Problémy periférních oblastí. Praha: Univerzita Karlova v Praze. Prírodovedecká Fakulta, $184 \mathrm{pp}$

OuŘEdníčeK M., 2003. Suburbanizace Prahy. Sociologický časopis, vol. 39, no. 2, pp. 235-253.

Perlín R., ŠimíčKová A., 2008. Criteria of a successful rural municipality. Europa XXI, vol. 17, Warsaw: Institute of Geography and Spatial Organization. Polish Academy of Sciences, pp. 29-43.

PTÁČEK P., 1997, Suburbanizační proces v zázemí Prahy v 1. polovině 90. let. Územní plánování a urbanismus, vol. 24, no. 1-2, pp. 13-14

RuMPEL P., SiWEK T., 2006. Marketing terytorialny a kreowanie regionów: przykład czeski. Przegląd Geograficzny, vol. 78, iss. 2, pp. 191-205.

SIWEK T., 1988. Území Československa očima studentů geografie. Geografie. Sborník Československé geografické společnosti, vol. 93, no. 1, pp. 31-37.

SIWEK T., 1995. Narodowość ślqska w byłej Czechosłowacji. [in:] K.D. Kadłubiec (ed.), Kultura ludowa na pograniczu, Prace Naukowe Uniwersytetu Ślaskiego w Katowicach, no. 1520, Katowice: Uniwersytet Ślaski, pp. 46-53.

SIWEK T., 2002a. Morawianie. Sprawy Narodowościowe. Seria nowa, vol. 11, no. 20, pp. 125-137.

SIWEK T., 2002b. Czeskie miasta po roku 1989. [in:] J. Słodczyk (ed.), Przemiany bazy ekonomicznej i struktury przestrzennej miast. Opole: Uniwersytet Opolski, pp. 45-52.

SIWEK T., 2005. Laicisation process in Czechia: spatial analysis. [in:] E. Klima (ed.), Religion in the time of changes, Space-Society-Economy, vol. 7, Łódź: University of Łódź. Department of Space Economy and Spatial Planning, pp. 227-233.
SIWEK T., 2006. Czech Silesia: a periphery of the Czech State. Europa XXI, vol. 15, Warsaw: Institute of Geography and Spatial Organization. Polish Academy of Sciences, pp. 145-150.

SIWEK T., 2007. Morawianie i Ślqzacy w Republice Czeskiej: mniej niż naród, więcej niż region. [in:] M.W. Wanatowicz (ed.), Józef Chlebowczyk - badacz procesów narodotwórczych, Prace Naukowe Uniwersytetu Śląskiego, no. 2463, Katowice: Wydawnictwo Uniwersytetu Śląskiego, pp. 145-155.

SiWEK T., BogdovÁ K., 2007. České kulturně-historické regiony ve vědomí svých obyvatel. Sociologický časopis, vol. 43, no. 5, pp. 1039-1053.

SiWEK T., Bogdová K., 2008. Badania tożsamości terytorialnej w Republice Czeskiej. [in:] E. Orłowska (ed.), Kulturowy aspekt badań geograficznych. Studia teoretyczne i regionalne. Tom 5, Wrocław: Polskie Towarzystwo Geograficzne, Instytut Geografii i Rozwoju Regionalnego Uniwersytetu Wrocławskiego, pp. 45-56.

SiWEK T., KaŇOK J., 2000. Vědomí slezské identity v mentální mapě. Spisy Filozofické fakulty Ostravské univerzity, vol. 136, Ostrawa: Ostravská univerzita, 97 pp.

SPILKOVÁ J., 2007. Foreign firms and the perception of regions in the Czech Republic: A statistical examination. Tijdschrift voor Economische en Sociale Geografie, vol. 98, no. 2, pp. 260-275.

SPOUSTA J., 1999. České církve očima sociologických výzkumů. [in:] J. Hanuš (ed.), Náboženství v době společenských změn, Brno: Masarykova univerzita, pp. 73-90.

SRB V., 1997. Náboženské vyznání a demografické, sociálněekonomické a kulturní charakteristiky obyvatelstva. Demografie, vol. 39, no. 3, pp. 191-292.

StANĚK T., 1991. Odsun Němců z Československa 1945-1947. Praha: Academia - Naše vojsko, 536 pp.

SÝKORA L. (ed.), 2002. Suburbanizace a její sociální, ekonomické a ekologické důsledky. Praha: Ústav pro ekopolitiku, 191 pp.

Ž́́ČEK R., 1995. Z historii regionalizmu i separatyzmu morawskiego. [in:] M. Wanatowicz (ed.), Regionalizm a separatyzm - historia i współczesność. Ślqusk na tle innych obszarów. Katowice: Wydawnictwo Uniwersytetu Ślqaskiego, pp. 149-157.
(C) Tadeusz Siwek

(C) Geographia Polonica

(C) Institute of Geography and Spatial Organization,

Polish Academy of Sciences, Warsaw, 2012
Article first received • January 2012

Article accepted • June 2012 
http://rcin.org.pl 